\title{
EFFECTS OF NANO SILVER PARTICLES AND GIBBERELLIC ACID ON GROWTH AND SOME PHYSIOLOGICAL CHARACTERISTICS OF DALBERGIA SISSOO ROXB.
}

\author{
Bahra J. Swara ${ }^{\mathrm{a}, *}$, Ikbal M. Al-barzinji ${ }^{\mathrm{b}}$ \\ ${ }^{a}$ Dept. of Medical Microbiology, Faculty of Science and Health, Koya University, Koya KOY45, Kurdistan Region - F.R. \\ Iraq. (bahra.jabar@koyauniversity.org) \\ ${ }^{\mathrm{b}}$ Dept. of Biology, Faculty of Science and Health, Koya University, Koya KOY45, Kurdistan Region - F.R. Iraq. \\ (ikbal.tahir@koyauniversity.org)
}

Received: Jan., 2021 / Accepted: May., 2021 / Published: Jun.,2021

https://doi.org/10.25271/sjuoz.2021.9.2.789

\begin{abstract}
:
Recent studies show that Nanotechnology can be effectively used to enhance the characteristics of many types of trees including forest trees. Dalbergia Sissoo Roxb., which belongs to the Fabaceae family, is a forest tree that grows in dry land and water conservation areas. The aim of this study is to examine the effect of nano silver (NS) at $(0,30,60 \mathrm{and} 90 \mathrm{mg} / \mathrm{L})$ and gibberellic acid $\left(\mathrm{GA}_{3}\right)$ at $(0,50,100$ and $200 \mathrm{mg} / \mathrm{L})$ concentrations on seed performance and subsequent growth of Dalbergia sissoo Roxb. The results reveal the enhancement of germination rate and velocity by using $\mathrm{GA}_{3}$ at 100 and $200 \mathrm{mg} / \mathrm{L}$. NS90 treatment increased each of shoot and root fresh and dry weight, leaf area and plant height whereas GA50 treatment increased number of branches per plant and primary root length. Non-significant differences between treatments on Peroxidase enzyme activity and chlorophyll a content was observed whereas NS30 had the highest chlorophyll b and lowest total carotenoids. Shoot and root contents of some essential and non-essential elements differed between treatments. In roots, N90 treatment increased each of $\mathrm{Cu}$ and $\mathrm{Mn}$ elements, but it decreased $\mathrm{Cl}$ content. Although GA100 treatment increased $\mathrm{Cl}$ content, it decreased $\mathrm{Mn}$. The paper concludes that the applications of nano-silver and $\mathrm{GA}_{3}$ on Dalbergia sissoo Roxb. have significant effects on its growth and physiological parameters.
\end{abstract}

KEYWORDS: Dalbergia sissoo Roxb., Germination, Gibberellin, Nano Silver, Peroxidase Enzyme and Vegetative Growth.

\section{INTRODUCTION}

Dalbergia sissoo Roxb. is an important legume tree belonging to family Fabaceae (Sehra and Sharma, 2021). It mainly grows along riverbanks below a height of 900 meters, but can naturally reach up to 1300 meters. The mean temperature in its natural range is $10-40{ }^{\circ} \mathrm{C}$, but varies from just below freezing to almost $50{ }^{\circ} \mathrm{C}$. It can survive annual average rainfall of up to 2,000 millimeters. It grows in the range of soils from perfect sand and gravel to rich alluvium of banks of the river; it can grow in slightly salty soils (Adenusi and Odaibo, 2009). Dalbergia Sissoo is among the most valuable tree species commonly recommended for afforestation and reforestation programs in dry land and water conservation areas (Joshi et al., 2021). It is used as a wind break, shelter belt and nitrogen fixation. Also, its highly valued wood is used for making furniture and for constructional and general utility purposes (Naqvi et al., 2019). Its leaves, young shoots and green pods, are important sources of fodder (Bhattacharya et al., 2014), and its seed oil and roots which contain tectoridin used medicinally (Sehra and Sharma, 2018). The developments in agricultural science are continuous especially in plant physiology and throughout the last century developed from plant hormones to nanotechnology. Thus, Nanotechnology as a revolutionary contemporary science can play an enormous role in improving the quality of Dalbergia Sissoo Roxb. and increasing their production (Singh et al., 2021).

Many studies have been conducted using nano silver on different plant species for improving seed performance and their subsequent growth such as in fenugreek (Trigonella foenum-graecum) where AgNPs enhanced seed germination and early seedling growth (Hojjat and Hojjat, 2015). In their study of bishop pine (Pinnus muricata) Sweet and Singleton (2015) found that after 1 month AgNP had significantly reduced the root length of pine seedlings. However, after 4 months growth, AgNP levels utilized had significantly reduced both pines root and shoot biomass. Stimulatory effects reported on root elongation, fresh weight, and evapotranspiration of poplars (Populus tremula) and arabidopsis (Arabidopsis thaliana) (Wang et al., 2013).

Plant hormones are another practice used for improving plant growth and development where the plant hormone gibberellins are used for improving seed performance in many species such as horse gram (Macrotyloma uniflorum) where germination percentages were significantly accelerated by $\mathrm{GA}_{3}$ (Lalitha et al., 2016). According to AlHawezy (2013) who has studied seed germination of loquat (Eriobotrya japonica), $\mathrm{GA}_{3}$ has a significant effect on increasing germination rate as compared to control. Another study was determined to reduce faba bean (Vicia faba) flowers abortion and increase seed production by $\mathrm{GA}_{3}$ foliar spraying. Its results indicated that plant height, number of branches/plant, number of pods/plant, number of seeds/pod, number of seeds/plant as well as seed yield significantly exceeded (Kandil et al., 2011).

Due to the dearth of research about effects of NS on Dalbergia Sissoo Roxb. growth, and the desire to increase the cultivated area of this important tree, this study has been conducted which is about the effects of NS and $\mathrm{GA}_{3}$ in

\footnotetext{
* Corresponding author

This is an open access under a CC BY-NC-SA 4.0 license (https://creativecommons.org/licenses/by-nc-sa/4.0/)
} 
different concentrations on the growth and some physiological characteristics of Dalbergia Sissoo.

\section{MATERIAL AND METHODS}

\subsection{Plant Material and Chemicals}

The ripe pods of Dalbergia Sissoo tree which was 15 years old collected on July 19, 2018 from Mnara Park/Erbil. Pods with one seed was selected. The experiment for this study was conducted in a private field in Taqtaq city, Koysinjaq,

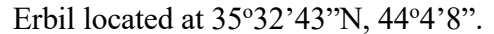

The nano silver made in US Research Nanomaterials, Inc (CAS: 7440-22-4, USA). For preparing $90 \mathrm{mg} / \mathrm{L}$ nano silver, $0.1809 \mathrm{~g}$ of nano silver $(99.5 \%)$ dissolved in $5 \mathrm{ml}$ of ethanol then completed to $2 \mathrm{~L}$ by distilled water, this treatment denoted as NS90 and as an original solution, whereas each of NS60 and NS30 were prepared from the original solution. The gibberellic acid made from Avonchem limited (CAS: 7706-5, UK). For preparing $200 \mathrm{mg} / \mathrm{L} \mathrm{GA}_{3}, 0.412 \mathrm{~g}$ of gibberellic acid $(97 \%)$ dissolved in $5 \mathrm{ml}$ of ethanol then completed to $2 \mathrm{~L}$ by distilled water, this treatment denoted as GA200 and as an original solution, whereas each of GA100 and GA50 were prepared from the original solution.

\subsection{Treatment Procedure}

On January 10, 2019, poly bags sized (10x10x30) cm was filled with soil-peat moss mixture of (1:1). Then on January 17,2019 , the cut pods soaked in the solutions of nano silver (30, 60 and $90 \mathrm{mg} / \mathrm{L}), \mathrm{GA}_{3}(50,100$ and $200 \mathrm{mg} / \mathrm{L})$ in addition to distilled water as control for $24 \mathrm{hrs}$. On the next day, 3 seeds were planted in each poly bags, (figure 1). The experiment was completed on July 4, 2019.

\subsection{Meteorological Data and Soil Properties}

Table (1) illustrates the maximum and minimum temperatures, the relative humidity and the amount of rainfall in the field during the planting season which were registered by the Agro-Meteorological station in Taqtaq city, Koysinjaq, Erbil.

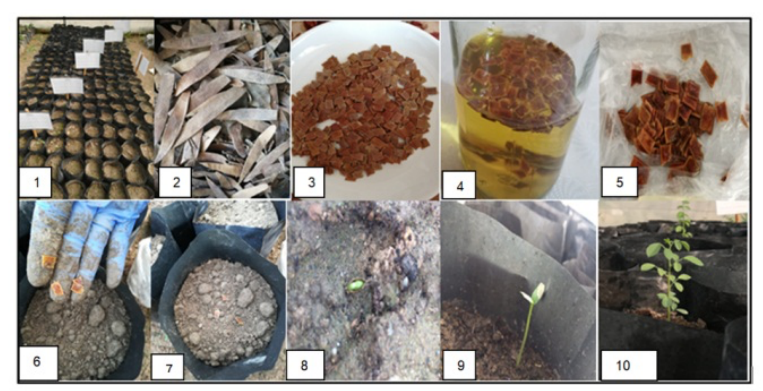

Figure 1. Seed planting procedure (1) preparing seeds bags (2) ripe seeds (3) cut seeds (4) soaking in treatments solutions (5) raising from solutions (6) planting (7) covering (8) emerging (9) two leaves seedling (10) plant stalk

Table 1. Meteorological data during the growing season (2019)

\begin{tabular}{|l|c|c|c|c|c|}
\hline \multirow{3}{*}{ Months } & \multicolumn{2}{|c|}{$\begin{array}{c}\text { Temperature } \\
\left({ }^{\circ} \mathbf{C}\right)\end{array}$} & \multicolumn{2}{c|}{ Relative humidity (\%) } & $\begin{array}{c}\text { Rain } \\
\text { fall } \\
(\mathbf{m m})\end{array}$ \\
\cline { 2 - 5 } & maximum & minimum & maximum & minimum & \\
\hline January & 16.4 & 6.6 & 74.5 & 51.4 & 74.5 \\
\hline February & 18.3 & 7.9 & 86.1 & 48.1 & 86.1 \\
\hline March & 22.5 & 12.5 & 208.4 & 52.7 & 208.4 \\
\hline April & 35.4 & 22.1 & 129.0 & 47.4 & 129.0 \\
\hline May & 48.4 & 29.7 & 25.4 & 12.0 & 25.4 \\
\hline June & 56.9 & 36.5 & 0 & 13.0 & 0 \\
\hline July & 49.5 & 29.5 & 0 & 5.5 & 0 \\
\hline
\end{tabular}

The experiment soil taken from the Srusht Nursery in Taqtaq. Then the physical and chemical properties of the soil (as shown in table (2)) were determined by Agricultural Research Center/ Ainkawa/ Erbil, Department of Soil and Water Science at University of Sulaimanya and Department of Physics at Koya University.

Table 2. Some characteristics of the study soil

\begin{tabular}{|c|c|}
\hline Property & Value \\
\hline $\mathrm{EC}(\mathrm{Ds} / \mathrm{m})$ & 0.3 \\
\hline $\mathrm{pH}$ & 7.68 \\
\hline Organic Matter (\%) & 1.12 \\
\hline $\mathrm{HCO}_{3}(\%)$ & 1.093 \\
\hline $\mathrm{CO}_{3}(\%)$ & 0 \\
\hline $\mathrm{CaCO}_{3}(\%)$ & 34.95 \\
\hline Sand $(\%)$ & 51.5 \\
\hline Silt (\%) & 24.1 \\
\hline Clay (\%) & 24.4 \\
\hline Soil texture & Sandy clay \\
\hline $\mathrm{Ca}$ & 38.60 \\
\hline K & 4.26 \\
\hline $\mathrm{Mg}$ & 3.80 \\
\hline $\mathrm{S}$ & 0.83 \\
\hline $\mathrm{Cu}$ & 0.02 \\
\hline $\mathrm{Fe}$ & 8.96 \\
\hline $\mathrm{Ni}$ & 0.02 \\
\hline $\mathrm{Si}$ & 31.10 \\
\hline $\mathrm{Zn}$ & 0.06 \\
\hline $\mathrm{Al}$ & 8.78 \\
\hline $\mathrm{Br}$ & 0.004 \\
\hline $\mathrm{Cl}$ & 0.14 \\
\hline $\mathrm{Mn}$ & 0.28 \\
\hline $\mathrm{Rb}$ & 0.0184 \\
\hline $\mathrm{Sr}$ & 0.10 \\
\hline $\mathrm{Ti}$ & 1.12 \\
\hline
\end{tabular}

\subsection{Germination and Vegetative Growth Characteristic Studies}

The germination rate was measured as indicated in Ahmadloo et al. (2012), the velocity of emergence was measured as showed in Ranal and Santana (2006), the plant height, number of branches per plant, length of the primary root, number of leaves per plant was measured as demonstrated by Khudhur and Omer (2015), dry and fresh weight (shoot and root) and dry matter (root and shoot) were measured as specified by Al-Sahaf, (1989), leaf area was calculated using the method described by Watson and Watson (1953).

\subsection{Chemical Analysis}

Total carotenoids pigments of chlorophylls a and b calculated as mentioned by Lichtenthaler and Wellburn (1983), total carbohydrate determined using the method outlined by Joslyn (1970), Peroxidase enzyme activity in leaf observed as it is stated by Nezih (1985) and chemical elements of root and shoots discovered using X-ray fluorescence (XRF) spectroscopy as explained by Haschke (2014) and Rodrigues et al. (2018). 


\subsection{Experimental Design and Statistical Analysis}

Randomized Complete Block Design (RCBD) consisted of 7 treatments which are control (distillate water), NS30, NS60, NS90, GA50, GA100 and GA200, each treatment with 3 replications and 10 bags for each experimental unit.

The Duncan's multiple comparison test used to assess the main treatment effects that varied when the F-value was significant at $\leq 0.05$ using the statistical analysis system (SAS Program, 2005).

\section{RESULTS AND DISCUSSION}

\subsection{Germination Rate and Velocity}

Results in table (3) show that treated seeds of Dalbergia Sissoo with $100 \mathrm{mg} / \mathrm{L} \mathrm{GA}_{3}$ increased the percent of seeds germination to $80 \%$ which is significant compared to other $\mathrm{GA}_{3}$ treatments and the highest concentration of nano silver $90 \mathrm{mg} / \mathrm{L}$, which may due to toxic effects of NPs that may have substantial negative effects, such as reduction in seed (Yang et al., 2017). Generally, there were non-significant differences between various concentrations of nano silver treatments, and the result was in line with the findings of Krishnaraj et al. (2012). The seed germination and other physiological activities could increase by applying of plant growth regulator at high concentration this is mainly because tolerance to toxic effects of $\mathrm{GA}_{3}$ which was found to be consistent with the findings of Hoque and Haque (2002). Increased effectiveness of low concentrations of $\mathrm{GA}_{3}$ may lead to the restoration of water content retardation; this may be due to water stress intolerance, which is parallel with the findings of Roychowdhury et al. (2012).

Table 3. Effect of nano silver and gibberellic acid on Dalbergia sissoo germination rate and velocity.

\begin{tabular}{|l|c|c|}
\hline Treatments & $\begin{array}{c}\text { Germination } \\
\text { rate (\%) }\end{array}$ & $\begin{array}{c}\text { Velocity of } \\
\text { emergence (days) }\end{array}$ \\
\hline Control & $70.00 \mathrm{a} \mathrm{b}$ & $45.33 \mathrm{a}$ \\
\hline NS30 & $63.33 \mathrm{a} \mathrm{b}$ & $41.96 \mathrm{a} \mathrm{b}$ \\
\hline NS60 & $53.33 \mathrm{a} \mathrm{b}$ & $44.22 \mathrm{a} \mathrm{b}$ \\
\hline NS90 & $40.00 \mathrm{~b}$ & $44.75 \mathrm{a} \mathrm{b}$ \\
\hline GA50 & $56.67 \mathrm{a} \mathrm{b}$ & $47.00 \mathrm{a}$ \\
\hline GA100 & $80.00 \mathrm{a}$ & $47.13 \mathrm{a}$ \\
\hline GA200 & $50.00 \mathrm{a} \mathrm{b}$ & $39.27 \mathrm{~b}$ \\
\hline
\end{tabular}

* According to the Duncan test all above (means) in the same column which have similar letter are not considerably different at $p \leq 0.05$.

According to the results, velocity of emergence of seeds was accelerated significantly when $\mathrm{GA}_{3}$ at $200 \mathrm{mg} / \mathrm{L}$ was used compared to control, 50 and $100 \mathrm{mg} / \mathrm{L}$ of $\mathrm{GA}_{3}$.

Table 4. The Effect of nano silver and gibberellic acid on some vegetative growth of Dalbergia sissoo plant

\begin{tabular}{|c|c|c|c|c|c|c|c|c|c|c|c|}
\hline Trea & \begin{tabular}{|c|}
$\begin{array}{c}\text { Shoot } \\
\text { fresh } \\
\text { Weight } \\
\text { (g) }\end{array}$ \\
\end{tabular} & $\begin{array}{c}\text { Root } \\
\text { Fresh } \\
\text { Weight } \\
\text { (g) } \\
\end{array}$ & $\begin{array}{l}\text { Shoot } \\
\text { Dry } \\
\text { Weight } \\
\text { (g) } \\
\end{array}$ & $\begin{array}{c}\text { Root } \\
\text { Dry } \\
\text { Weight } \\
\text { (g) } \\
\end{array}$ & $\begin{array}{l}\text { Leaf } \\
\text { Area } \\
\left(\mathrm{cm}^{2}\right)\end{array}$ & \begin{tabular}{|c|}
$\begin{array}{c}\text { Number } \\
\text { of } \\
\text { Branches }\end{array}$ \\
/Plant
\end{tabular} & \begin{tabular}{|c|} 
Length of \\
Primary \\
Root \\
$(\mathrm{cm})$ \\
\end{tabular} & $\begin{array}{c}\text { Number } \\
\text { of } \\
\text { Leaf/ } \\
\text { Plant } \\
\end{array}$ & \begin{tabular}{|c|} 
Plant \\
Height \\
$(\mathrm{cm})$
\end{tabular} & $\begin{array}{l}\text { Shoot } \\
\text { Dry } \\
\text { Matter } \\
(\%) \\
\end{array}$ & $\begin{array}{c}\text { Root } \\
\text { Dry } \\
\text { Matter } \\
(\%) \\
\end{array}$ \\
\hline Control & $3.20 \mathrm{~d}$ & $1.15 \mathrm{~d}$ & $0.80 \mathrm{~d}$ & $0.45 \mathrm{e}$ & $314.9 \mathrm{~d}$ & $20.00 \mathrm{~d}$ & $13.13 \mathrm{e}$ & $57.0 \mathrm{e}$ & $15.00 \mathrm{~d}$ & $24.93 \mathrm{~d}$ & $39.66 \mathrm{abc}$ \\
\hline NS30 & $8.73 \mathrm{~b}$ & $3.60 \mathrm{ab}$ & $2.50 \mathrm{bc}$ & $1.20 \mathrm{~b}$ & $801.0 \mathrm{c}$ & $29.00 \mathrm{cb}$ & $15.73 \mathrm{~d}$ & $99.0 \mathrm{~d}$ & $43.50 \mathrm{~b}$ & $28.66 \mathrm{bcd}$ & $33.33 \mathrm{c}$ \\
\hline NS60 & $10.56 \mathrm{a}$ & $4.05 \mathrm{a}$ & $3.85 \mathrm{a}$ & $1.50 \mathrm{a}$ & $1666.9 \mathrm{a}$ & $27.66 \mathrm{c}$ & $22.76 \mathrm{~b}$ & $164.3 \mathrm{~b}$ & $55.50 \mathrm{a}$ & $35.50 \mathrm{a}$ & $37.03 \mathrm{bc}$ \\
\hline NS90 & $7.13 \mathrm{c}$ & $2.55 \mathrm{c}$ & $2.15 \mathrm{c}$ & $0.95 \mathrm{c}$ & $662.1 \mathrm{c}$ & $26.33 \mathrm{c}$ & $15.66 \mathrm{~d}$ & $139.3 \mathrm{bc}$ & $26.73 \mathrm{c}$ & $30.10 \mathrm{bc}$ & $37.26 \mathrm{bc}$ \\
\hline GA50 & $8.10 \mathrm{bc}$ & $3.10 \mathrm{~b}$ & $2.70 \mathrm{~b}$ & $1.40 \mathrm{a}$ & $907.1 \mathrm{cb}$ & $38.00 \mathrm{a}$ & $29.73 \mathrm{a}$ & $126.0 \mathrm{~cd}$ & $50.50 \mathrm{ab}$ & $33.13 \mathrm{ab}$ & $46.33 \mathrm{a}$ \\
\hline GA100 & $8.90 \mathrm{~b}$ & $3.10 \mathrm{~b}$ & $2.69 \mathrm{~b}$ & $1.10 \mathrm{~b}$ & $1078.0 \mathrm{~b}$ & $33.33 \mathrm{ab}$ & $22.26 \mathrm{~b}$ & $204.3 \mathrm{a}$ & $47.00 \mathrm{ab}$ & $30.30 \mathrm{bc}$ & $35.46 \mathrm{bc}$ \\
\hline GA200 & $3.40 \mathrm{~d}$ & $1.40 \mathrm{~d}$ & $0.87 \mathrm{~d}$ & $0.58 \mathrm{~d}$ & $396.2 \mathrm{~d}$ & $27.33 \mathrm{c}$ & $19.83 \mathrm{c}$ & $66.6 \mathrm{e}$ & $48.50 \mathrm{ab}$ & $26.23 \mathrm{~cd}$ & $42.40 \mathrm{ab}$ \\
\hline
\end{tabular}

This result agrees with that of Awatif and Alaaeldin (2017) whom confirmed that seed pre-treatment with GAs promote seed germination not only through stimulation of hydrolyzing enzymes but also by antagonizing the inhibitory effect of ABA on germination process. From the table, it is also seen that all tested concentrations of nano silver, germination period was decreased in comparison with control treatment, it is also seen in the result of Kumar et al. (2020) whom stated that seed of wheatgrass (Agropyron elongatum L.) germination time decreased significantly from 4.01 to 1.68 days by using silver nanoparticles, and it refers to the activation of respiration and rapid ATP production (Azimi et al., 2014).

\subsection{Vegetative Growth}

The impact of nano silver and gibberellic acid on vegetative growth of Dalbergia Sissoo seedling aged 5 months, described in table (4). The nano silver had more effect on the leaf area, dry and wet weight of root and shoot, while the low concentrations of gibberellic acid was highly effective on length of primary root, number of branch, plant height and number of leaf. Nano silver of $60 \mathrm{mg} / \mathrm{L}$ concentration and 50 treatments. The lowest effect in all parameters (except number of leaf) acquire by NS90. Moreover, GA200 had lowest value in root dry weight, number of branch and length of primary root, while it had non-significant effect on leaf area, number of leaf, root fresh weight and shoot weight (dry and fresh). The results agreed with those of Al-Imam (2007), Delvadia et al. (2009), Yaseen et al. (2016) and Jasim et al. (2017).

The increases of growth parameters were mediated via elongation (El-Batal et al., 2016). In that respect, at high concentration nano silver reduce all growth parameters compared to other treatments. This reduction at higher doses may be attributed to toxic level of nanoparticles. Sahandi et al. (2011) and Salama (2012) also observed these results. In addition, the result indicates that nano silver and gibberellic acid treatments are significantly effective on the percentage of shoot dry matter, whereas NS60 had the highest value and GA200 had the lowest value. Besides nano silver treatments and GA100 had no effect on root dry matter percent, while $50 \mathrm{mg} / \mathrm{L}$ gibberellic acid was significantly affected.

\subsection{Chemical Compositions}

Table (5.) illustrates that nano silver and gibberellic acid had significant effect on chlorophyll $\mathrm{b}$ and total carotenoids. $\mathrm{mg} / \mathrm{L}$ of gibberellic acid were more effective than the other gibberellic acid were due to the cell division and cell 
The highest values were observed by NS30 and GA100 for chlorophyll $\mathrm{b}$ and total carotenoids but the lowest values for total carotenoids and chlorophyll $b$ were by NS30 and GA100 respectively. All treatments had no significant effect on chlorophyll a content of leaf. Because of nanoparticles were passing through shoots after that assembled on leaves that cause disadvantage impact on tested plant chlorophyll content. The plant chlorophyll content may increases by low concentration, while may be decreased by high nanoparticle concentrations. Even though, the same results discovered by Mazumdar (2014) and Singh \& Kashyap (2015). The results of chlorophyll content treated by gibberellic acid agreed with Tsai \& Arteca (1985) and Stirk et al. (2019). The lower concentrations of NS and $\mathrm{GA}_{3}$ treatments had significant effect on increasing shoot total carbohydrate compared to other treatments. The carbohydrate in leaves was increased significantly with successive increase in the concentrations of nano silver particles. The impact factors of increasing carbohydrate of leaves may possibly be consistent with photosynthetic pigments for the correlating AgNPs treatments. As well as low concentrations of nano silver caused increasing soluble sugar (Yaseen et al., 2016). At the same time, nano silver treatment caused reduction in root carbohydrate. Reduction of the carbohydrate content may be attributed to the toxic level of nanoparticles resulting in a subsequent decrease in growth. Salama (2012) also obtained the same results. Although the results indicate that the effect of nano silver and gibberellic acid were non-significant on Peroxidase enzyme activity on leaves. Low activities of Peroxidase occurred in Dalbergia Sissoo treated with $\mathrm{GA}_{3}$ which is with accordance with finding of Khader et al. (1988) on mango fruit. On the other hand, the non-effective of nano silver may be due to the inactivation of the Peroxidase by the non-specific degradation of the enzyme proteins or the production of excessive free radicals (Zare et al., 2020).

Table 5. The Effect of nano silver and gibberellic acid on chlorophyll a, b and total carotenoids of leaf content in Dalbergia sissoo

\begin{tabular}{|c|c|c|c|c|c|c|}
\hline \multirow{2}{*}{ Treatments } & Chlorophyll a & Chlorophyll b & Total & \multicolumn{2}{|c|}{ Total carbohydrate (\%) } & \multirow{2}{*}{$\begin{array}{c}\text { Peroxidase } \\
\text { (absorbing units per } \\
\text { gram of fresh leaves) }\end{array}$} \\
\hline & \multicolumn{3}{|c|}{$\mathrm{mg} / \mathrm{g}$ fresh weight } & Shoot & Root & \\
\hline Control & $1.28 \mathrm{a}$ & $0.97 \mathrm{~b}$ & $0.16 \mathrm{c}$ & $11.83 \mathrm{c}$ & $22.20 \mathrm{c}$ & $943.30 \mathrm{a}$ \\
\hline NS30 & $1.27 \mathrm{a}$ & $1.36 \mathrm{a}$ & $0.01 \mathrm{e}$ & $25.10 \mathrm{a}$ & $18.90 \mathrm{c} \mathrm{d} \mathrm{e}$ & $1066.70 \mathrm{a}$ \\
\hline NS60 & $1.27 \mathrm{a}$ & $0.84 \mathrm{c}$ & $0.17 \mathrm{c}$ & $26.80 \mathrm{a}$ & $15.73 \mathrm{de}$ & $1128.40 \mathrm{a}$ \\
\hline NS90 & $1.26 \mathrm{a}$ & $0.79 \mathrm{c} \mathrm{d}$ & $0.19 \mathrm{~b}$ & $16.83 \mathrm{~b}$ & $21.13 \mathrm{~cd}$ & $919.30 \mathrm{a}$ \\
\hline GA50 & $1.25 \mathrm{a}$ & $0.76 \mathrm{de}$ & $0.20 \mathrm{~b}$ & $19.96 \mathrm{~b}$ & $35.00 \mathrm{a}$ & $1003.70 \mathrm{a}$ \\
\hline GA100 & $1.25 \mathrm{a}$ & $0.69 \mathrm{e}$ & $0.22 \mathrm{a}$ & $8.06 \mathrm{c}$ & $13.43 \mathrm{e}$ & $979.30 \mathrm{a}$ \\
\hline GA200 & $1.26 \mathrm{a}$ & $0.98 \mathrm{~b}$ & $0.12 \mathrm{~d}$ & $10.00 \mathrm{c}$ & $28.80 \mathrm{~b}$ & $1157.70 \mathrm{a}$ \\
\hline
\end{tabular}

* According to the Duncan test all above (means) in the same column which have similar letter are not considerably different at $p \leq 0.05$.

\subsection{Constituents of Macro and Micro Essential Elements}

According to the results in table (6), nano silver and gibberellic acid were significantly affected on macro and micro essential elements of shoot except Fe element. NS60 had the highest effect on $\mathrm{Mg}, \mathrm{Cu}$ and $\mathrm{Zn}$, it may due to the highest shoot and root fresh and dry weight (Table 4). In addition, the highest value of $\mathrm{K}$ was due to N90 treatment and for Mn was by GA50, these may be because this treatment had the highest root dry weight, number of branches per plant, and length of primary root, while the highest value of $\mathrm{Cl}$ was recorded by GA200 treatment. Oppositely, the lowest value was recorded by NS60 for K and Mn, NS90 for Mg,
GA50 for $\mathrm{Cl}$, NS30, GA50 and GA100 for $\mathrm{Cu}$ compared to control.

For root, the results in table (7) indicate that NS90 had highest effect on $\mathrm{Cu}$ and $\mathrm{Mn}$, while the highest value for $\mathrm{Cl}$ was due to GA100 treatment. Conversely, the lowest value was observed by NS90, GA50 and GA100, for $\mathrm{Cl}, \mathrm{Cu}$ and $\mathrm{Mn}$ elements respectively. Besides, nano silver and gibberellic acid had no significant effect on $\mathrm{Fe}, \mathrm{Zn}$ and macro elements.

Table (8) shows that (GA100 and GA200) impact on Br and NS60 on Rb were the highest and the lowest effect were noticed by control on $\mathrm{Br}$ and NS90 on Rb. In contrast, nano silver and gibberellic acid non-significantly affected on $\mathrm{Al}$, $\mathrm{Sr}$ and Ti elements in shoot.

Table 6. The Effect of nano silver and gibberellic acid on some macro and micro elements of shoot dry matter of Dalbergia Sissoo

\begin{tabular}{|l|c|c|c|c|c|c|c|}
\hline \multirow{2}{*}{ Treatments } & \multicolumn{2}{|c|}{ Macro elements (\%) } & \multicolumn{5}{|c|}{ Micro elements (\%) } \\
\cline { 2 - 8 } & $\mathbf{K}$ & Mg & Cl & Cu & Fe & Mn & Zn \\
\hline Control & $30.20 \mathrm{~b}$ & $3.66 \mathrm{~b} \mathrm{c}$ & $0.45 \mathrm{~b}$ & $0.05 \mathrm{a} \mathrm{b}$ & $0.88 \mathrm{a}$ & $0.71 \mathrm{a} \mathrm{b}$ & $0.06 \mathrm{~b}$ \\
\hline NS30 & $31.30 \mathrm{~b}$ & $4.46 \mathrm{a} \mathrm{b}$ & $0.44 \mathrm{~b}$ & $0.04 \mathrm{~b}$ & $0.90 \mathrm{a}$ & $0.58 \mathrm{~b}$ & $0.08 \mathrm{a} \mathrm{b}$ \\
\hline NS60 & $29.75 \mathrm{~b}$ & $4.97 \mathrm{a}$ & $0.56 \mathrm{~b}$ & $0.07 \mathrm{a}$ & $2.27 \mathrm{a}$ & $0.49 \mathrm{~b}$ & $0.14 \mathrm{a}$ \\
\hline NS90 & $37.10 \mathrm{a}$ & $3.05 \mathrm{c}$ & $0.64 \mathrm{a} \mathrm{b}$ & $0.06 \mathrm{a} \mathrm{b}$ & $0.81 \mathrm{a}$ & $0.60 \mathrm{a} \mathrm{b}$ & $0.10 \mathrm{a} \mathrm{b}$ \\
\hline GA50 & $33.60 \mathrm{a} \mathrm{b}$ & $4.03 \mathrm{a} \mathrm{b} \mathrm{c}$ & $0.37 \mathrm{~b}$ & $0.04 \mathrm{~b}$ & $0.57 \mathrm{a}$ & $0.85 \mathrm{a}$ & $0.07 \mathrm{~b}$ \\
\hline GA100 & $32.90 \mathrm{a} \mathrm{b}$ & $4.73 \mathrm{a} \mathrm{b}$ & $0.58 \mathrm{~b}$ & $0.04 \mathrm{~b}$ & $1.23 \mathrm{a}$ & $0.63 \mathrm{a} \mathrm{b}$ & $0.08 \mathrm{a} \mathrm{b}$ \\
\hline GA200 & $31.00 \mathrm{~b}$ & $3.98 \mathrm{a} \mathrm{b} \mathrm{c}$ & $0.89 \mathrm{a}$ & $0.05 \mathrm{a} \mathrm{b}$ & $1.21 \mathrm{a}$ & $0.65 \mathrm{a} \mathrm{b}$ & $0.11 \mathrm{a} \mathrm{b}$ \\
\hline
\end{tabular}

* According to the Duncan test all above (means) in the same column which have similar letter are not considerably different at $p \leq 0.05$. 
The antagonistic effects between $\mathrm{K}$ and $\mathrm{Rb}$ content in shoot is clear where NS90 treatment gave the highest content of K (Table 6), whereas it gave lowest value of $\mathrm{Rb}$ (Table 7), also $\mathrm{Mg}$ and $\mathrm{K}$ antagonistic is appear in shoots (Table 3.4) (Pik, et al., 2005 and Brataševec, 2013).

Furthermore, NS (except NS90) and $\mathrm{GA}_{3}$ treatments had no significant effects on $\mathrm{V}$. Referring to the root chemical elements the results indicate that NS30, GA50 and GA200 had the highest significant effect on $\mathrm{Sr}, \mathrm{Al}$ and $\mathrm{Ti}$ respectively. In contrast, the lowest value in $\mathrm{Al}$, $\mathrm{Ti}$ and $\mathrm{Sr}$ were noted by NS30 and GA200 compared to the control respectively. Moreover, nano silver and gibberellic acid had no significant effect on $\mathrm{V}, \mathrm{Br}$ and $\mathrm{Rb}$ in root. The decreasing of $(\mathrm{Br}$ and $\mathrm{Rb})$ in shoots and ( $\mathrm{Al}$ and $\mathrm{Ti}$ ) in root by using NS treatments which agrees with Yan and Chen (2019), stated that nano-silver may decrease root hair and inhibit root elongation (Table 4) which leads to inhibiting some minerals uptake.

Table 7. The Effect of nano silver and gibberellic acid on some macro and micro elements of root dry matter of Dalbergia Sissoo

\begin{tabular}{|l|c|c|c|c|c|c|c|}
\hline \multirow{2}{*}{ Treatments } & \multicolumn{2}{|c|}{ Macro elements (\%) } & \multicolumn{6}{|c|}{ Micro elements (\%) } \\
\cline { 2 - 8 } & $\mathbf{K}$ & $\mathbf{M g}$ & $\mathbf{C l}$ & $\mathbf{C u}$ & $\mathbf{F e}$ & $\mathbf{M n}$ & Zn \\
\hline Control & $31.50 \mathrm{a}$ & $3.79 \mathrm{a}$ & $2.18 \mathrm{~b}$ & $0.09 \mathrm{a} \mathrm{b}$ & $9.90 \mathrm{a}$ & $0.33 \mathrm{a} \mathrm{b}$ & $0.15 \mathrm{a}$ \\
\hline NS30 & $44.90 \mathrm{a}$ & $5.03 \mathrm{a}$ & $1.78 \mathrm{~b} \mathrm{c}$ & $0.08 \mathrm{a} \mathrm{b}$ & $3.40 \mathrm{a}$ & $0.29 \mathrm{a} \mathrm{b} \mathrm{c}$ & $0.18 \mathrm{a}$ \\
\hline NS60 & $29.72 \mathrm{a}$ & $4.26 \mathrm{a}$ & $1.85 \mathrm{~b} \mathrm{c}$ & $0.07 \mathrm{a} \mathrm{b}$ & $7.65 \mathrm{a}$ & $0.29 \mathrm{a} \mathrm{b} \mathrm{c}$ & $0.14 \mathrm{a}$ \\
\hline NS90 & $35.10 \mathrm{a}$ & $4.52 \mathrm{a}$ & $1.62 \mathrm{c}$ & $0.10 \mathrm{a}$ & $3.60 \mathrm{a}$ & $0.35 \mathrm{a}$ & $0.15 \mathrm{a}$ \\
\hline GA50 & $31.05 \mathrm{a}$ & $4.45 \mathrm{a}$ & $2.20 \mathrm{~b}$ & $0.05 \mathrm{~b}$ & $6.20 \mathrm{a}$ & $0.24 \mathrm{~b} \mathrm{c}$ & $0.13 \mathrm{a}$ \\
\hline GA100 & $35.10 \mathrm{a}$ & $4.57 \mathrm{a}$ & $4.12 \mathrm{a}$ & $0.08 \mathrm{a} \mathrm{b}$ & $5.49 \mathrm{a}$ & $0.22 \mathrm{c}$ & $0.15 \mathrm{a}$ \\
\hline GA200 & $30.50 \mathrm{a}$ & $4.51 \mathrm{a}$ & $1.94 \mathrm{~b} \mathrm{c}$ & $0.06 \mathrm{a} \mathrm{b}$ & $7.01 \mathrm{a}$ & $0.26 \mathrm{a} \mathrm{b} \mathrm{c}$ & $0.16 \mathrm{a}$ \\
\hline
\end{tabular}

* According to the Duncan test all above (means) in the same column which have similar letter are not considerably different at $p \leq 0.05$.

Table 8. Effect of nano silver and gibberellic acid on some beneficial and toxic elements of shoot and root dry matter of Dalbergia Sissoo

\begin{tabular}{|c|c|c|c|c|c|c|c|c|c|c|c|c|}
\hline \multirow{2}{*}{ Treatments } & \multicolumn{6}{|c|}{ Some Beneficial and Toxic Elements in Shoot } & \multicolumn{6}{|c|}{ Some Beneficial and Toxic Elements in Root } \\
\hline & $\mathbf{V}$ & Al & $\mathbf{B r}$ & $\mathbf{R b}$ & $\mathbf{S r}$ & $\mathbf{T i}$ & $\mathbf{V}$ & Al & $\mathbf{B r}$ & $\mathbf{R b}$ & $\mathbf{S r}$ & Ti \\
\hline Control & $0.01 \mathrm{~b}$ & $0.39 \mathrm{a}$ & $0.006 \mathrm{c}$ & $0.013 \mathrm{~d}$ & $1.28 \mathrm{a}$ & $0.07 \mathrm{a}$ & $0.02 \mathrm{a}$ & $4.06 \mathrm{a} \mathrm{b}$ & $0.02 \mathrm{a}$ & $0.027 \mathrm{a}$ & $0.63 \mathrm{~b} \mathrm{c}$ & $0.55 \mathrm{a} \mathrm{b}$ \\
\hline NS60 & $0.01 \mathrm{~b}$ & $1.19 \mathrm{a}$ & $0.007 \mathrm{c}$ & $0.035 \mathrm{a}$ & $1.46 \mathrm{a}$ & $0.12 \mathrm{a}$ & $0.03 \mathrm{a}$ & $4.25 \mathrm{a} \mathrm{b}$ & $0.01 \mathrm{a}$ & $0.021 \mathrm{a} \mathrm{b}$ & $0.49 \mathrm{~b} \mathrm{c}$ & $0.43 \mathrm{a} \mathrm{b}$ \\
\hline GA100 & $0.002 \mathrm{~d}$ & $0.77 \mathrm{a}$ & $0.019 \mathrm{a}$ & $0.031 \mathrm{a}$ & $2.95 \mathrm{a}$ & $0.08 \mathrm{a}$ & $0.03 \mathrm{a}$ & $3.49 \mathrm{a} \mathrm{b} \mathrm{c}$ & $0.03 \mathrm{a}$ & $0.014 \mathrm{~b} \mathrm{c}$ & $0.42 \mathrm{~b} \mathrm{c}$ & $0.43 \mathrm{a} \mathrm{b}$ \\
\hline GA200 & $0.007 \mathrm{c}$ & $0.61 \mathrm{a}$ & $0.019 \mathrm{a}$ & $0.018 \mathrm{c}$ & $1.51 \mathrm{a}$ & $0.09 \mathrm{a}$ & $0.03 \mathrm{a}$ & $4.46 \mathrm{a}$ & $0.01 \mathrm{a}$ & $0.011 \mathrm{c}$ & $0.23 \mathrm{bc}$ & $0.60 \mathrm{a}$ \\
\hline
\end{tabular}

* According to the Duncan test all above (means) in the same column which have similar letter are not considerably different at $p \leq 0.05$.

\section{CONCLUSIONS AND RECOMMENDATIONS}

The study concludes that application of nano silver on Dalbergia Sissoo seeds especially at $60 \mathrm{mg} / \mathrm{L}$ significantly increases certain vegetative growth parameters, shoot carbohydrate and certain of chemical nutrients. $\mathrm{GA}_{3}$ mainly 50 and $100 \mathrm{mg} / \mathrm{L}$ significantly increases germination rate, a number of vegetative growth parameters, total carotenoids, shoot and root carbohydrate compared to other gibberellic acid concentrations. In addition to investigating the effects of nano-silver and gibberellic acid on the anatomical changes in plants, it is recommended to conduct the experiments used in this study in different soil texture.

\section{REFERENCES}

Adenusi, A. A. and Odaibo, A. B. (2009). "Effects of varying concentrations of the crude aqueous and ethanolic extracts of Dalbergia Sissoo plant parts on Biomphalaria pfeifferi egg masses." African Journal of Traditional, Complementary and Alternative Medicines 6(2):139 149

Ahmadloo, F., Tabari, M., Yousefzadeh, H., Kooch,Y. and Rahmani, A. (2012). "Effects of soil nutrient on seedling performance of Arizona cypress and medite cypress." Annals of Biological Research 3(3): 1369-1380.

Al-Hawezy, S. M. N. (2013). "The role of the different concentrations of $\mathrm{GA}_{3}$ on seed germination and seedling growth of loquat (Eriobotrya japonica L.)." IOSR Journal of Agriculture and Veterinary Science 4(5): 3-6.AlImam, N. M. A. A. (2007). "Effect of soaking periods, gibberellic acid, and benzyladenine on pistachio seeds germination and subsequent seedling growth (Pistacia vera L.)." Mesopotamia Journal of Agriculture 35(2): 28.

Al-Sahaf, F. H. (1989). "Applied Plant Nutrition". Baghdad, AlHikma House. [In Arabic].

Awatif S. Ali and Alaaeldin A. Elozeiri. 2017. Metabolic Processes During Seed Germination, Advances in Seed Biology, Jose C. Jimenez-Lopez, IntechOpen, DOI: 10.5772/intechopen.70653. Available from: https://www.intechopen.com/books/advances-in-seedbiology/metabolic-processes-during-seed-germination

Azimi, R., Borzelabad, M.J., Feizi, H. and Azimi, A. (2014). Interaction of $\mathrm{SiO} 2$ nanoparticles with seed prechilling on germination and early seedling growth of tall wheatgrass (Agropyron elongatum L.), Pol. J. Chem. Technol. 16: 9 25 .

Bhattacharya, M., Singh, A. and Ramrakhyani, C., (2014). "Dalbergia Sissoo-an important medical plant. " Journal of Medicinal Plants, 2(2):76-82.

Brataševec, K. (2013). Detremination of the actual uptake of essential nutrients by different parts of Vitis vinifera L. cv. Rebula. Dessertation. University of Nova Gorcia. Slovenia. 
Delvadia, D. V., Ahlawat, T. R. and Meena, B. J. (2009). "Effect of different $\mathrm{GA}_{3}$ concentration and frequency on growth, flowering and yield in gaillardia (Gaillardia pulchella Foug.) cv. Lorenziana." Journal of Horticultural Sciences 4(1): 81-84.

El-Batal, A. I., Gharib, F. A. E. L., Ghazi, S. M., Hegazi, A. Z. and Hafz, A. G. M. A. E. (2016). "Physiological responses of two varieties of common bean (Phaseolus vulgaris $\mathrm{L}$.) to foliar application of silver nanoparticles." Nanomaterials and Nanotechnology 6: 13-29.

Haschke, M. (2014)." Laboratory micro-X-Ray fluorescence spectroscopy,"Springer Series in Surface Sciences 55: 206.

Heera, P. and Shanmugam, S. (2015). "Nanoparticle characterization and application: an overview." Int. J. Curr. Microbiol. App. Sci 4(8): 379-386.

Hojjat, S. S. and Hojjat, H. (2015). "Effect of nano silver on seed germination and seedling growth in Fenugreek seed." International Journal of Food Engineering 1(2): 106-110.

Hoque, M. and Haque, S. (2002). "Effects of $\mathrm{GA}_{3}$ and its mode of application on morphology and yield parameters of mungbean (Vigna radiate L.)." Pak. J. Biol. Sci. 5(3): 281-283.

Jasim, B., Thomas, R., Mathew, J. and Radhakrishnan, E. K. (2017). "Plant growth and diosgenin enhancement effect of silver nanoparticles in fenugreek (Trigonella foenum-graecum L.)." Saudi Pharmaceutical Journal 25(3): 443-447.

Joshi, S., Jaggi, V., Gangola, S., Singh, A., Sah, V.K. and Sahgal, M. 2021. "Contrasting rhizosphere bacterial communities of healthy and wilted Dalbergia Sissoo Roxb. forests. "Rhizosphere, 17:100295.

Joslyn, M. A. (1970). "Analítico: Methods in food analysis. Physical, chemical, and instrumental methods of analysis 2nd Edition. New York, Academic press: 844.

Kandil, A. A., Sharief, A. E. M. and Mahmoud, A. S. A. (2011). "Reduction of flower dropping in some faba bean cultivars by growth regulators foliar application." Journal of Plant Production 2(11): 1439-1449.

Khader, S. E. S. A., Singh, B. P. and Khan, S. A. (1988). "Effect of $\mathrm{GA}_{3}$ as a post-harvest treatment of mango fruit on ripening, amylase and Peroxidase activity and quality during storage." Scientia Horticulturae 36(3-4): 261-266.

Khudhur, S. A., and Omer, T. J. (2015). Effect of NAA and IAA on stem cuttings of Dalbergia Sissoo (Roxb). Journal of Biology and Life Science, 6(2): 208-220.

Krishnaraj, C., Jagan, E. G., Ramachandran, R., Abirami, S. M., Nohan, N. and Kalaichelvan, P. T. (2012). "Effect of biologically synthesized silver nanoparticles on Bacopa monnieri (Linn.) Wettst. plant growth metabolism." Process Biochemistry 47(4): 651-658.

Kumar, V. K., Muthujrishnan, S. and Rajalakshmi, R. (2020)."Phytostimulatory effect of phytochemical fabricated nanosilver (AgNPs) on Psophocarpus tetragonolobus (L.) DC. seed germination: An insight from antioxidative enzyme activities and genetic similarity studies." Current Plant Biology 23: 100158.

Lalitha, J., Rafath, H. and Subash, M. (2016). "Effect of gibberellic acid and indole-3-acetic acid on seed germination performance of horse gram (Macrotyloma uniflorum) Lam (Verdc)." Journal of Applied and Advanced Research 1(2): 36-40.

Lichtenthaler, H. K. and Wellburn, A. R. (1983). Determinations of total carotenoids and chlorophylls a and $\mathrm{b}$ of leaf extracts in different solvents." Biochemical Society Trtansaction 11(5): 591-592.
Mazumdar, H. (2014). "The impact of silver nanoparticles on plant biomass and chlorophyll content."International Journal of Engineering and Science 4(7): 12-20.

Naqvi, S. A. H., Mushtaq, S., Malik, M. T., Umar, U.-D., Rehman, A., Fareed, S. and Zulfiqar, N. A. (2019). "Factors leading towards Dalbergia Sissoo decline (Syndrome) in Indian sub-continent: A critical review and future research agenda." Pakistan Journal of Agricultural Research 32(2): 302-316.

Nezih, M. (1985). "The Peroxidase enzyme activity of some vegetables and its resistance to heat". Food Agric. 36: $877-880$.

Pik, H.O., Rolfe, S.A. and Willis, A.J. (2005). The Physiology of Flowering Plants. Fourth Edition. Cambridge University Press, UK.

Ranal, M. A. and Santana, D. G. d. (2006). "How and why to measure the germination process?" Brazilian Journal of Botany 29(1): 1-11.

Rodrigues, E. S., Gomes, M. H. F., Duran, N. M., Cassanji, J. G., Da Cruz, T. N. M., Neto, A. S., Savassa, S. M., Almeida, E. D. and De Carvalho, H. W. P. (2018). "Laboratory microprobe X-ray fluorescence in plant science: emerging applications and case studies." Frontiers in Plant Science 9: 1588.

Roychowdhury, R., Mamgain, A., Ray, S. and Tah, J. (2012). "Effect of gibberellic acid, kinetin and indole 3-acetic acid on seed germination performance of Dianthus caryophyllus (Carnation)." Agriculturae Conspectus Scientificus 77(3): 157-160.

Sahandi, S. M., Sorooshzadeh, A., Rezazadeh, H. S. and Naghdibadi, H. A. (2011). "Effect of nano silver and silver nitrate on seed yield of borage." Journal of Medicinal Plants Research 5(2): 171-175.

Salama, H. M. H. (2012). "Effects of silver nanoparticles in some crop plants, common bean (Phaseolus vulgaris L.) and corn (Zea mays L.)."International Research Journal of Biotechnology 3(10): 190-197.

SAS. (2005). "statistical analysis system institute, cary NC, USA.

Sehra, Y.S. and Sharma, J. (2021). "Preventive potential of Dalbergia Sissoo Roxb. on dmba-induced skin carcinogenesis in mice." Plant Archives, 21(1):18521855.

Sehra, S.Y. and Sharma, J., (2018). "Pharmacological effects and medicinal importance of Dalbergia Sissoo- a review. " International Journal of Pharmaceutical, Chemical \& Biological Sciences, 8(2): 234-243.

Singh, D., Arya, S., Gupta, B., Kaushik, D., Arya, V.S., Kumar, U. and Singh, K., (2021). "Applications of Nanotechnology in Forest Management. " Journal of Nanoscience and Nanotechnology, 21(6): 3466-3480.

Singh, G. and Kashyap, L. (2015). Effect of different hormones on plant attribute and yield of field pea (Pisum Sativum L.), Doctoral dissertation, Lovely Professional University. http://dspace.lpu.in:8080/jspui/bitstream/123456789/359 3/1/11309054_6_26_2015\%202_2039\%20PM_thesis\%2 0by\%20gurjinder\% 20 singh.pdf.

Stirk, W.A., Tarkowská, D., Gruz, J., Strnad, M., Ördög, V. and van Staden, J. (2019). "Effect of gibberellins on growth and biochemical constituents in Chlorella minutissima (Trebouxiophyceae). "South African Journal of Botany 126(2019): 92-98.

Sweet, M. J. and Singleton, I. (2015). "Soil contamination with silver nanoparticles reduces Bishop pine growth and ectomycorrhizal diversity on pine roots." Journal of Nanoparticle Research 17(11): 448. 
Tsai, D.S. and Arteca, R. N. (1985). "Effects of root applications of gibberellic acid on photosynthesis and growth in $\mathrm{C} 3$ and C4 plants." Photosynthesis Research 6(2): 147-157.

Wang, J., Koo, Y., Alexander, A., Yang, Y., Westerhof, S., Zhang, Q., Schnoor, J.L., Colvin, V.L., Braam, J. and Alvarez, P.J.(2013)." Phytostimulation of poplars and Arabidopsis exposed to silver nanoparticles and $\mathrm{Ag}+$ at sublethal concentrations. "Environmental Science and Technology 47(10): 5442-5449.

Watson, D. J. and Watson, M. A. (1953). "Comparative physiological studies on the growth of field crops: iii. the effect of infection with beet yellows and beet mosaic viruses on the growth and yield of the sugar-beet root crop." Annals of Applied Biology 40(1): 1-37.
Yan, A. and Chen, Z. (2019). Impacts of silver nanoparticles on plants: a focus on the phytotoxicity and underlying mechanism. Int. J. Mol. Sci. 2019, 20(5): 1003.

Yang, J., Cao, W. and Rui, Y. (2017). Interactions between nanoparticles and plants: phytotoxicity and defense mechanisms. Journal of Plant Interactions 12(1):158-169.

Yaseen, A. A. M., Khalidah, M. S., Basim, S. and Wasan, M. H. (2016). "Effect of foliar spray of nano silver and organic fertilizer (Algastar) and salicylic acid on some morphological characteristics and carbohydrate content in (Helianthus annuus L.)." Journal of Agriculture and Ecology Research International 9(3): 1-7.

Zare, Z., Pishkar, L., Iranbakhsh, A. and Talei, D. (2020). "Physiological and molecular effects of silver nanoparticles exposure on purslane (Portulaca oleracea L.). "Russian Journal of Plant Physiology, 67: 521-528. 